\title{
Public-private re-alignments: the role of structural economic transformations in spurring the joint international engagement of agribusiness and the Brazilian State
}

\author{
Niels Søndergaard1
}

\begin{abstract}
The article focuses upon how changes in global agricultural markets and the transformation of the Brazilian economic model from the 1990s have redefined relations between the state and agribusiness, and affected the country's international strategy. The central objective is to evaluate the causal impact of structural factors at the global and the national level upon the dispositions and preferences of the group of actors examined. Public-private cooperation is analyzed through institutionalist IPE and liberal IR theory, in combination with a neopluralist perspective. The article concludes that changes in global food markets and the economic liberalizations of the 1990s have spurred an export-oriented consensus between the agricultural sector and the state, with strong repercussions within the country's international engagement.
\end{abstract}

Keywords: Agriculture, Interest Groups, Agribusiness, International Trade, WTO.

\section{Introduction}

The present article analyses how changes of global agricultural markets, in combination with the structural transformation of the Brazilian economy have redefined the state-agribusiness relationship, and how this alignment has impacted upon the country's participation within international commercial negotiations. The central objective is therefore to evaluate the causal impact of structural factorsat the global and the national level upon the dispositions and preferences of the groups of actors examined, in order to explain theirexercise of

\footnotetext{
${ }^{1}$ MSc. em Estudos Globais e Ciência Política da Lund Universitet. Doutorando no Instituto de Relações Internacionais (IREL), Universidade de Brasília (UnB). Bolsista Capes. E-mail: niels@soendergard.dk.
} 
influence upon trade policy. An essential explanatory character is therefore ascribed to the variables of 1) changes within global agricultural markets, and 2) the structural transformation of the Brazilian economy from the 1990s, in order to explain the joint international engagement between agribusiness and the state.The analysis hereby bridges the division between the levels of structure and agency. An intermestic focus is applied in order to understand how developments at the global level affect domestic actors and institutions, which in terms adopt an international orientation and participation. The article relies on institutionalist international political economy (IPE) perspectives upon internationalization in order to account for the socio-economic restructurings resultant from increasingly interconnected global markets. The relationship between government and interest groups is treated through a liberal IR approach to domestic preference aggregation and a neopluralist perspective upon interests articulation. The article concludes that agribusiness has assumed an economic significance in recent decades, that has provided the sector with a domestic political leverage, which spills directly over into the Brazilian foreign engagement.

\section{Internationalization, domestic preferences and political changes}

The consequences which structural changes in global markets wield upon the policy preferences of domestic economic actors have been treated within institutionalist IPE perspectives. Milner and Keohane (1996) ascribe a high degree of explanatory causal significance to the notion of 'internationalization' which they relate to increased efficiency of international transactions, accompanied by the proliferation of capital and surges in trade. As internationalization affects the relative capacity of domestic economic groups to engage with international markets, these actors will tend to influence national policy institutions to obtain the most favorable regulation (MILNER; KEOHANE, 1996, p. 4). The variation in recourse endowments and the competitive potential of domestic economic actors are factors, which to a high degree define how internationalization shapes the reorientation of their preferences towards national policy institutions (Ibid, p. 16). Frieden and Rogowski (1996) have also elaborated on the domestic political consequences of exogenous transformations within global markets. These authors emphasize decreased transportation costs, increased financial integration, productive interconnection and economies of scale, as wielding a significant impact upon the structure of policy preferences of socioeconomic and political actors (FRIEDEN; ROGOWSKI, 1996, p.26-28). The new set of preferences is transmitted 
through a reconfiguration of domestic political institutions which eventually affects national policy formation (Ibid, p. 26-28). Common to these aforementioned institutionalist IPE perspectives is therefore, that they position the preferences and agency of domestic economic actors as a vital intermediate link between structural economic transformations at the global level, and the changes within national institutions and policy formation.

Through the elaboration of his liberal theory of international politics, Andrew Moravcsik (1997; 1998) adopts a "bottom-up" perspective, by which the aggregated interests of societal groups are believed to be internalized and advanced by the state (MORAVCSIK, 1997, p. 517-518). In spite of being less emphatic about the significance of the systemic economic level, Moravcsik nonetheless accentuates the influence of international market incentives upon the political demands of domestic producers, particularly within trade policies (MORAVCSIK, 1998, p.38). Influential groups pursue their interests through institutions which represent them, and so define the array of preferences which the state seeks to realize within the constraints of interstate bargaining (MORAVCSIK, 1997, p. 519-520). The state's engagement within international commercial negotiations is thereby conditioned by the conjunction of impulses emanating from constituencies facing potential economic gain, and constrains imposed by negative distributional consequences of such accords, at home and abroad (MORAVCSIK, 1998, p.38). The general account of how economic factors spill over into institutional and political change through the preferences of domestic groups, thus presents some similar features within both the institutionalist IPE perspective and Moravcsik's liberal theory. Upon this, it becomes interesting to evaluate the particular manner in which the interaction between the state and private actors unfolds, and how influence is exercised. From the neopluralist perspective, Lindblom and Woodhouse $(1977 ; 1993)$ stress the significance of private actors within the policy making process, which often materializes as a "privileged position of business" (LINDBLOM, 1977, p.172). This position rests upon a range of factors, such as financial and organizational capacity, a high degree of direct access to the political sphere, and the ability to articulate particular interests as a broader societal concern, due to the potentialeconomic spillover effects (LINDBLOM, 1977, p.194; LINDBLOM; WOODHOUSE, 1993, p.101). The result is an engagement between private and public entities in a process of "mutual adjustment," generally accommodating corporate interests (LINDBLOM, 1977, p.174). Finally, interest groups may also exercise influence through the formation of coalitions, which can provide strong private stakeholder support for certain political 
agendas (LINDBLOM \& WOODHOUSE, 1993, p.78). The neopluralist contribution thereby implies a strong emphasis upon the analysis of private-public interaction as a deliberative process, by which mutual concerns and overlapping interests result in a close alignment revolving around certain strategic objectives.

The theoretical revision leads to the formulation of a causal relationship which the following analysis evaluates. The first independent variable is presented as the structural changes of global agricultural markets, which in more specific terms is treated as the increasing degree of global commercialization, productive interconnection, financialization of agriculture, the scalar restructuring towards an industrial cultivation model as well as the institutional pressures towards liberalization. The second independent variable, though not directly theoretically derived, is treated as the structural transformation of the Brazilian economy from the 1990s, which becomes highly relevant as a historical contextual factor that defines much of the agricultural restructuring during this period.The dependent variable is treated as the institutionalization and execution of a joint public-private strategy within international trade negotiations. The change of preferences and political participation of private domestic actors constitutes a central causal mechanism, which is presumed to link the explanatory and the dependent variables.

\section{Global agricultural market transformations}

Towards the end of the 20th century, structural shifts within global agricultural markets wielded a significant impact upon Brazilian rural sectors. The general trend of increasing international commercial integration also became pronounced within agriculture, and food trade nearly doubled in the period 1980-2000 from US $\$ 243$ to US\$467 billion (AKSOY, 2005, p.22). As production chains gained global extension, technological, cultivation and consumption patterns were similarly streamlined due to concentration of the agricultural market structure (PAULA \& BASTOS, 2008, p.3). This standardization of the global agro-food system meant that international market demand was concentrated upon asmall handful of widely commercialized multifunction bulk crops. Soy and corn were particularly central in this respect, and global soy production soared in the period 1985-2005 from 101 to 214 million ton, while corn increased from 485 to 713 million ton (FAO, 2016). From the end of the 1970s, there has been a profound decline in the global shipping costs for bulk commodities, such as grains (HUMMELS, 2007, p.243). A significant parallel trend to the physical integration of agricultural markets, has also been the 
proliferation of international regulation within the field in the 1990s. Agriculture had until then largely been excluded from GATT, meaning that regulation had been a matter pertaining the domestic policy levels of member states (COLEMAN, 2003, p.4). Yet, by the 1970s and 1980s, crises within the agricultural sectors in many countries led to the nascent efforts to insert agriculture within the institutional structure of the international trading system. This was widely promoted by an incipient transnational epistemic community within the area of agricultural economics (Idem). An essential aspect of the Agreement of Agriculture of 1994 also had to do with the inclusion of internal support measures within the scope of international commercial governance (COELHO; WERNECK, 2004, p. 7). The developments within the institutional dimension of agricultural markets transmitted a range of neoliberal imperatives (CAVALCANTI; KRONE, 2015, p. 117) which were largely in line with the logic of the Washington Consensus, predominant at the time. Lessa et al. (2009) accentuate that the Brazilian foreign strategy of the 1990s was strongly characterized by an urge towards participation within the international system, resulting in the eager internalization of the neoliberal policy prescriptions of the day. Two central and interrelated dynamics came to determine the conformation of the domestic Brazilian agricultural regime to international obligations; the opening to international investment and the dismantling of internal support measures. As Diniz (1996) stresses, the proliferation of support for neo-liberal policies domestically was strongly linked to the gradual exhaustion of the model of import-substitution (DINIZ 1996, p. 56). Though divergence still existed with regards to its specific formulation, a relatively broad consensus nonetheless prevailed within the Brazilian business elites, regarding an agenda of economic opening implying deregulation, privatization and the retreat of the state (DINIZ, 1996, p. 69). Thus, though systemic impacts did wield a significant influence upon the restructuring of the rural sector in Brazil, they did so in close reciprocity with endogenously rooted transformations. This does not diminish the importance of changes within global agriculture for Brazil at the time, but on the contrary, meant that they could proliferate even deeper ina fertile political environment.

The rise of global agribusiness has strongly characterized the sociology and political economy of agriculture in the 1990s (BUTTEL, 2001, p. 21). Another central trend within agricultural markets in this period has been the surge of financialization, which has become manifest throughout the entirety of agrarian production chains (FAIRBARN, 2015, p. 234). Corporate penetration and financialization here by constitute two essential intertwined structural dynamics 
within the global political economy of agriculture, which also led to the internal restructuring and re-orientation of the Brazilian rural sector. In this respect, the Brazilian Constitution of 1988 hadestablished a foothold for foreign capital within the agricultural sector, by providing a significant legal guarantee for investors(WELCH,2006, p. 42). Yet, agriculturally related foreign direct investment (FDI) only began to surge more markedly in the middle of the 1990s, towards a climax in 2004 when they constituted 29,4\% of total FDI (NASCIMENTO, 2011, p. 16-18).Foreign investments within Brazilian agriculture have in most cases become realized through either contract farming, capital market investments, partnerships and joint ventures, or by direct investments in transportation, storage and harborage (MAPA, 2010, p. 67).The increasing presence of foreign capital was paralleled by cutbacks on public agricultural credit through the 1990s, which meant that particularly large-scale agriculture came to rely upon foreign financing of production; either from the corporations specialized in the provision of seed and fertilizer inputs or from multinational trading companies (MULLER; MULLER, 2011, p. 44). Interest rates offered by trading companies are often much more favorable to producers than those of private Brazilian banks (PEINE, 2009, p. 90). Consequently, contract farming, - whereby seller and buyer agree upon product standards and future delivery - also became widespreadand was officially institutionalized through the bill draft law 4.378 from 1998, which established the legal regime upon which the practice could rest, defining a set of rights and obligations of both the agro-industry and the particular farmer (WATANABE; ZYLBERSZTAJN, 2014, p. 474-475). Contract farming functions as a financial derivative model, which ensures vertical integration and close synchronization within extensive agribusiness production systems, thereby limiting transaction costs (Ibid, p. 461) and most importantly in this regard, orients production towards global, rather than domestic demand. The increasing presence of multinational trading companies has been particularly strong within the soy sector. Bungee, Louis Dreyfus, Cargill and ADM together account for $59 \%$ of crushing and $61 \%$ of exports, through a logistical network which stretches from product purchase to shipping facilities (SCHLESINGER, 2008, p.9; ALBANO; DE SÁ, 2011, p. 66). The entry and consolidation of the agribusiness model has thereby created a production structure which is intrinsically linked to the globalagrofood system. Large proportions of Brazilian agriculture have thereby been connected through both forward and backward linkages to global commodity and financial markets. Developments in Brazil are parallel to those within global commodity markets in recent decades, where trading companies and financial institutions have become very central 
in connecting the processes of production and distribution to the logic of financial calculus and trading (MURPHY et al. 2012, p. 6).Though significant proportions of typical export crops are consumed internally, domestic demand is more stabile. Additional profit generation therefore depends upon increased allocation abroad, and in this manner, further international market access becomes central to domestic producers. Re-arrangements produced by the insertion of foreign capital within Brazilian agriculture have hereby formed a structural link, which directly couples profits of domestic rural producers to events beyond the national level.

In spite of the dismantling of rural credits, total Brazilian agricultural production grew firmlyin the 1990s and early 2000s, in large part due to technological inflows which spurred the restructuring towards industrial agriculture (BELIK, 2007, p. 166). In the middle of the 1990s, global prices surged for crops with a high potential for foreign commercialization such as soy, cotton and sugar cane (CAVALCANTI; KRONE, 2015, p. 119). Between 1990-2005, exportoriented monocultures advanced, as soy production rose from 19 to 51 million ton, cotton from 1,7 to 3,6 million ton, and (raw) sugarcane from 262 to 422 million ton (IBGE, 2016). Combined with the reduction in state intervention, this meant that capital accumulation became more dependent upon events within global, rather than national markets (BERALDO, 2000, p. 3). The externally induced changes in production and financing structures wielded a strong influence upon the sector's internal composition and triggered the outwards orientation of agribusiness. A combination of relatively abrupt credit cuts and the elevated interests rates of the Plano Real monetary stabilization program, meant that particularly smallholders were strongly affected: while average productivity from 1980-2000 increased by $40 \%$, the new financial conditions meant that average gross income for farmers fell by 40\%; pushing many small farmers out of business. (RODRIGUES, 2001, p. 7) The exchange rate appreciation from 1994-1999 also had a generally depressing effect upon real prices (BRAUN et al. 2007, p. 48). With the devaluations of 1999 which occurred in tandem with increasing global food prices, the benefits in large came to fall upon organized - and capital intensive - exportoriented agriculture (DE MELO, 1999, p. 148; BELIK, 2007, p. 166-167). The financial conditions created by anti-inflationary policies and exchange rate adjustments, thereby benefitted commodity export sectors relative to other parts of the economy (ARBIX, 2010, p. 269). Technological intensification and mechanization due to the expansion of export crops such as soy, coffee and cotton in the 1990s, along with the introduction of GMO seeds in the 2000s also led to the loss of many 
jobs within agriculture (WELCH, 2006, p. 46). From 1992 to 2009, agricultural employment dropped from $2,8 \%$ to $1,7 \%$ of the workforce (WORLDBANK, 2016). Mendonça (2015) identifies a historical tendency within Brazilian agricultural policies to associate development with technological progress, and thus to endorse the notion ofagribusiness and favor export-oriented sectors. The incorporation of actors "beyond the farm gate" such as input providers and trading companies within this vision, is pinpointed by Mendonça as a significant trend of the 1990s. (MENDONÇA, 2015, p. 392) Yet, in spite of the entry of foreign enterprises in this period, direct production and some processing activities are still dominated by Brazilian companies: 35 of the country's 40 leadingagricultural firms are of national origin, many of which have made incursions into activities otherwise dominated by international traders, such as financing, processing, transport and commercialization (HOPEWELL, 2014, p. 297; PEINE, 2009). Brazilian agriculture hasthereby undergone a profound restructuring in recent decades, brought about by global market changes, (BELIK, 2007, p. 163) adoption of a technology intensive productive model (PAULA; BASTOS 2009, p. 7) and international liberalizations (BRAUN et al. 2007, p. 43). The institutionalist IPE literature's emphasis upon transaction costs reduction and international market transformation, thus also appears to offer a fitting point of departure, in order to understand the changes within Brazilian agriculture during this period. The effects of exogenous easing within the international economy upon the intensification of patterns of global agricultural trade and investment were structural impacts which fundamentally altered the composition of Brazilian agriculture. This has been expressed by new cleavages between internally and externally oriented sectors, brought about by internationalization and resulting in the relative strengthening of the latter. It therefore becomes relevant to evaluate how this new market positioning and incentive structure affected the political preferences of agents within the agricultural sector. Because although important shifts in global agricultural markets have indeed led to changes within Brazil, these transformations did not unfold in vacuum. Rather, this transition was perceived, mediated, contested and enforced by a diversity of actors. This process hereby unfolded through a structurally induced push which reshaped the dispositions and strategic perceptions of agribusiness towards embracing liberalization; domestically and abroad. 


\section{Re-orientation of the state}

The fundamental changes in the economic orientation of the Brazilian state from the 1990s may be difficult to completely distinguish from the general process of globalization of markets in this period. Yet, though external ideological and economic winds did influence events within Brazil, the structural transformation of the country's economic model is nonetheless characterized by a range of endogenous dynamics. It therefore becomes relevant to examine the re-orientation of the state as a separate analytical variable.The role assumed by Brazilian agribusiness within the state's strategy for international opening in the 1990s must in largebe understood through the foreign revenue which the sector provides. A yearly surplus on the agricultural trade balance between US\$10-15 billion from 1994 to 2000 was vital in order to prevent a more dangerous deficit on the overall negative total trade balance in the last part of the 1990s (RODRIGUES, 2001, p. 8). Agricultural revenues also became an important factor in producing the substantial current account surpluses from 2000 to 2005 (MAPA 2010, p. 15). The economic model of the 1990s rested upon concerns related to diminished governmental economic participation, privatizations, primary surplus generation and attraction of foreign investments (CERVO, 2008, p. 78): all of which served to stimulate export-oriented agriculture. The reforms thereby provided an environment in which agribusiness could reach an unprecedented level of competitiveness (LOPES et al. 2002, p. 21). During the liberalizations, agriculture gained a new significance as the state partly shifted its focus away from import substituting manufacturing, towards prioritizing export sectors. This also meant that global market access for agricultural products became a strong foreign policy concern. (HOPEWELL 2014, p. 294) Hereby, a fundamentally new societal purpose was ascribed to the agricultural sector.

With the structural transformation of the Brazilian economy, a history of significant governmental participation within agrarian markets came to an end. The first programfor agro-industrial development had been instituted in the Plano de Metas of the Juscelino Kubitscheck government 1956-1961 (BELIK, 2007, p. 157). Another landmarkin this respect was the establishment of SNCR credit system Sistema Nacional de Crédito Rural - in 1965 (Ibid, p. 158). Up until the 1970s, the Brazilian state was strongly engaged in mandating export quotas, import controls and stockpiling of food commodities. Due to its purpose of subsidizing the reproduction of the urban labor force, agricultural policy became subjected the goal of national industrialization (MENDONÇA, 2015, p. 395). In the aftermath of re- 
democratization from 1985, liberal ideology gained an increasingly firm foothold within Brazil (WELCH, 2006, p. 37). When Collor de Mello assumed the presidency in 1990, he embarked upon a profound restructuring of the developmental paradigm, from a model based in large part upon import substitution, towards one of commercial liberalization (SABA, 2002, p. 199). A broad unilateral economic opening was thereby introducedand the average level of tariff protection was lowered from 35\% to 20\% (RODRIGUES; DE LUCENA, 2003, p. 409). During the governments of Collor de Mello (1990-1992) and Itamar Franco (1992-1994), extensive deregulatory reforms of Brazilian agriculture were introduced (WELCH, 2006, p. 37). The redefinition of the rural economic model became expressed through an emphasis upon the notion of "modernization" which weighted privatization of land markets above agricultural reform (MENDONÇA, 2015, p. 394). The Collor government considered that public involvement in the agricultural sector should be restructured so as to incentivize "agro-industrialization" (REZENDE, 1999, p. 76). The phaseout of the state's direct involvement, combined with the creation of a regulatory environment which favored private investment, provided a firm institutional structure for the growth of market-oriented agribusiness (MULLER; MULLER, 2006, p. 6). On the other hand, the drastic changes of agricultural policies from 1990-1994 led to the exclusion of a large number of the rural population, as family farmers were put out of business (WELCH, 2006, p. 43). Pressures for agrarian reform in the post-authoritarian period were set aside in favor of growth in capital-intensive sectors, which exacerbated rural exodus (MENDONÇA, 2015, p. 396). The export sectors - increasingly concentrated on a few large producers - had to a large extend come to define rural development, due to a strong financial capacity and a high degree of market power (CORTE, 2013, p. 12).

The state's new liberal perspective upon the purpose of the agricultural sector resulted in a series of specific measures to benefit branches with a high international competitive potential. One of the most significant steps in this respect was the exemption of raw materials and semi-manufactures from payment of the Imposto de Calculo de Mercadoria e Serviços (ICMS) in September 1996- a tax upon internal circulation of commodities which significantly had reduced the incentive for foreign commercialization (RODRIGUES; DE LUCENA, 2003, p. 414). The law, which became known as the Lei Kandir (the Kandir Law) came to stand as an important victory for Brazilian agribusiness (RODRIGUES, 2001, p. 10). Particularly the soy sector benefitted markedly from the abolishment of taxes on grains, soy cake and oil. This immediately raised the price for producers but also 
worked to push soy exports upwards in the long term (WARNKEN, 1999, p. 78; TAGLIALEGNA et al. 2000, p. 42).

The policy restructurings at the time were not minded upon the entire rollback of all public economic involvement within the agricultural sector. Rather, they were meant to adapt the state's participation to a more market-oriented regulatory model, and to limit the previously broad range of support measures to a few core functions. The governmental involvement in minimum price setting and inventory holding of agricultural products was sought to be restricted and simplified with the creation of the programs of Prêmio de Escoamento de Produtos (PEP), and the Contrato de Opções de Venda de Produtos Agrícolas in 1997(COVPA), administered by the public agency, CONAB (MULLER; MULLER, 2014, p. 45). While the PEP means to streamline the various minimum price guarantees and support product circulation around the country through public auctions (CONAB, 2015a), the COVPA aims at providing an optional price security mechanism for future deposition of products by the individual producers (CONAB 2015b).

The Lula administration from 2003 was characterized by the intend to reconcile an economic model based upon links with external forces of global capitalism, with an inwards looking development path (CERVO, 2008, p. 73-74). Its economic policies thereby contained traces of both liberal influences from the 1990s as well as the developmentalist tradition of previous times (BAN, 2012, p. 299). This same balance was initially pursued within the agricultural field, so that concerns of land reform, resettlements and internal food supply were placed alongside the interests of foreign capital and large-scale exportagriculture (ENGELMAN; GIL, 2012, p. 8). The Workers Party (PT) government managed to pass some significant programs with a focus upon strengthening smallholders and family agriculture, such as the National Plan for Agrarian Reform (PNRA), the National Program for Sustainable Development in Rural Territories (PRONAT) and the National Program for Enforcement of Family Agriculture (PRONAF). (CARVALHO, 2011, p. 6-7) Still, in the tradeoff between satisfying smallholder constituencies and agribusiness demands for expansion, the policies of the Lula government gradually came to tilt in favor of the later. This meant that resettlements were poorly implemented (ENGELMAN; GIL, 2012) and that land distribution remained highly unequal (IBGE, 2006). The process towards legalization of transgenic crops constitutes another issue within which the policies of the Lula government can be characterized as particularly attentive to agribusiness interests. After transgenic seeds had been illegally planted in the South for some years, pressures for legalization finally resulted 
in a presidential decree which temporarily legalized commercialization (DAROIT, 2007, p. 152). After further temporary concessions, a new Biosecurity Law which opened up for the use of transgenic seeds was finally signed by Lula in 2005 (BRAZIL Lei № 11.105, 2005).

The vital importance of agricultural exports within the development model pursued by the Brazilian state from the turn of the century (HOPEWELL, 2013, p. 608) may to a wide extend explain the inclination of public policies towards agribusiness during this period. The rural policies during the Lula administration thereby appear to reflect how internationalization of markets not only implies an increased exposure of national economies, but also imposes a range of financial imperatives, which to some degree reduce the macroeconomic policy-making autonomy of governments. Though initially a balanced approach between agribusiness and family agriculture was pursued, the sheer proportion of the external revenues generated by agribusiness - and their vital role as a basis for the redistributive economic model pursued at the time, - were difficult to ignore. Vieira (2013) through an analysis of Brazilian trade and foreign policy in recent decades, points toward the significance of systemic determinants, rather than ideological orientation, in defining Brazilian foreign economic engagement during the Lula period. It thus appears that the logic implied by these economic constraints embedded within the international level has been directly transmitted to the domestic sphere, at which it stimulated, and in the intermediate term generously rewarded policies biased towards a commodity export-based development model.

\section{Institutionalizing a joint foreign strategy}

Although some compelling elements differentiate the economic models of the Cardoso and Lula administrations, a common focus upon coordinating the competitive global insertion of certain domestic sectors can be identified as an element of continuity. Around the turn of the millennium, the need to generate foreign liquidity became a major imperative, which spilled directly over into trade policy and market access (VAZ, 2003, p. 141). The last Cardoso periodwas characterized by an intent to diminish dependence on foreign capital in favor of the adoption of an export-oriented strategy, which in spite of a change in rhetoric, was carried over into the first Lula term. This pragmatism of the 2003- centre-left government is also expressed by the direct inclusion of agribusiness representatives within it (VIEIRA, 2013, p. 13). The foreign commercial strategy implied a strong support for the internationalization of national enterprises (CERVO; BUENO, 2011, p. 
544-545) which in the case of Brazilian agribusiness became effective through the state's efforts to raise the issue of protectionism and domestic subsidies at the multilateral sphere (CERVO, 2008, p. 86). Thus, in the course of both the Cardoso and Lula governments, agriculture became an important element within foreign policy planning, which also resulted in a direct involvement of agribusiness withinthis process (RAMANZINI JUNIOR; MARIANO, 2013, p.12071208). The increased inclusion of business and other domestic interest groups within foreign policy planning broke with a tradition of a ratherexclusive dominion of the field by the Foreign Ministry, Itamaraty. The high complexity and specificness of information needed within trade policy-making, though, called for the inclusion of private sectors which could offer this type of knowledge (HURREL; NARLIKAR, 2006, p. 427). This shift was largely provoked by the state's emerging perception of the importance of agribusiness, both in terms of exports and as a dynamic sector with a high employment potential (COELHO, 1999, p. 20).

Around the year 2000, a wide range of agricultural production chains had become internationally competitive (VIEIRA et al. 2001, p. 14). Yet, at the same time, this category of Brazilian exports faced some of the highest trade barriers in the Western hemisphere (JANK et al. 2004, p. 21). This made the agricultural sector organize in order to raise demands that government assumed a more aggressive stance within international trade negotiations (VEIGA, 2005). Towards the end of the Uruguay Round, the National Confederation of Agriculture (CNA) and other sector organizations also began to accompany negotiations, but the lack of internal coordination between them resulted in a largely defensive posture (BERALDO, 2000, p. 4). This changed in 1999 when CNA, the organization of Brazilian Cooperatives (OCB) and the Association of Brazilian Agribusiness (ABAG) created the 'Permanent Forum for Agricultural Negotiations' with the goal of influencing policy formation at the WTO (BERALDO, 2000, p. 4; CARVALHO, 2010, p. 417-418). Agribusiness thereby functioned both as a pressure group, which directly sought an impact upon negotiations at the WTO, but also as a mediator that could guarantee legitimacy and domestic support for the government's agenda at the international level (CARVALHO, 2010, p. 417). This mobilization materialized along sectorial lines, but also through cross-sector organizations, representing the generally offensive negotiation posture of exportoriented farming (HOPEWELL, 2014, p. 299). Thus, with the goal of obtaining firm results from the Doha Round, entities from Brazilian agribusiness funded the establishment of the Institute for International Trade Negotiations (ICONE) (CARVALHO, 2010, p.418). The Institute's 
mission was to provide technical knowledge, which became a vital recourse for the Brazilian delegation throughout the negotiations (HOPEWELL, 2013, p. 612). An informal technical group was furthermore created in order to manage the joint public-private efforts in the course of the Doha Round, below the coordination of Itamaraty (HOPEWELL 2014, p. 304). The 'Technical Group' consisted of the CNA, ICONE, the Ministry of Agriculture and Provisioning (MAPA), the Confederation of Agricultural Workers (Contag), The Ministry of Agrarian Development (MDA) and the Ministry of Development, Industry and Foreign Commerce (MDIC) (CARVALHO 2010, p. 419). The "bottom-up" perspective advanced by Moravcsik (1998), through which the structure of national preferences is seen as an aggregation of the interests of significant domestic stakeholders, appears to imply a largely satisfactory description of the process of increasing agribusiness interest representation in Brazilian foreign trade planning. Yet, the question remains as to whether the articulation of private preferences causally antecedes the preference formation of public decision makers, as the reviewed theoretical perspectives indicate. The process of joint mobilization and institutionalization of a foreign strategy, rather reflects that the manifestation of agribusiness concerns has occurred simultaneously with the pro-active engagement of the state, in order to embrace ruralinterests, as national interests. Such anaccount appears to approximate Vigevani and Cepaluni (2007, p. 274) who warn against exaggerating the importance of private sector influence as a determinant of Brazilian foreign policy, due to a high degree of bureaucratic insulation. The process reviewed indicates thatBrazilian agricultural organizations did exercise a certain degree of influence, which nonetheless became effective through a convergence of interests with the state. Particularly the relationship between rural entities and the Foreign Ministry appears to have been shaped by mutual preferences and overlapping objectives. In line with Lindblom (1977), this development also demonstrates the private sector's ability to articulate its own interests in a manner such that they become intertwined with the concerns for the generalsocietal welfare - and in a foreign policy view, - with broader national goals. The process of institutional formation between the state and agribusinesshereby reflects the significance of private sector organizational and institutional recourses, when business and governmentengage in a deliberative process of pursuing mutual objectives.

\section{Strategic cooperation between the state and agribusiness}

During most of the post-war period, agricultural policy making was essentially confined to the domestic spheres of individual states. In the 
1980s, focus was increasingly directed towards the institutionalization of international regulatory mechanisms and an incipient transnational policy space was formed, wherein governments, rural organizations and agribusiness became central actors (COLEMAN, 2003, p. 4). The Uruguay Round further enlarged and intensified this policy space, which also came to include developing countries (Ibid, p.7). In spite of only representing $10-13 \%$ of global trade at the time, agriculture was one of the most hard-lived obstacles to overcome during the negotiations, particularly due to pressures for maintaining internal subsidies from Northern producers (ALMEIDA, 2012, p. 81; THORSTENSEN, 2005, p. 67). This resulted in a situation in which the Agreement on Agriculture became an unprecedented - though incomplete - landmark for global agricultural regulation. Particularly Southern agro-exporting nations craved for extending its scope.

Ahead of the Seattle Ministerial Conference of 1999, the Brazilian agricultural sector and government managed to reach a common position. This was based upon the goal of deepening the reform of certain elements of the Agreement on Agriculture, such as market access, internal support measures and export subsidies (BERALDO, 2000, p. 4; CARVALHO, 2003, p. 387). Agriculture was one of the most hotly debated issues at Seattle, and agreement was reached regarding the initiation of a new round of negotiations the following year (THORSTENSEN, 2005, p. 490). Though Seattle 1999 did not lead to any concrete results, it became significant for Brazilian rural interests as they managed to form a common front with much influence upon the country's official posture (BERALDO, 2000, p. 4). This determined public-private domestic consensus also paved the ground for Brazil's central positioning within a coalition of developing countries, focused upon mutual goals of ambitious and offensive demands (CARVALHO, 2010, p. 423; DIEGO-FERNANDES, 2008, p. 432).

The pressures for agricultural liberalizations were thereby carried on into the Doha negotiations from 2001, within which they constituted a central issue (DEADORF; STERN, 2009, p. 527). During the preparatory meetings toward the initiation of the IV WTO Ministerial Conference in Doha, Brazil sought to raise the issues of internal support measures, export subsidies and non-trade concerns (TELEGRAM. 1311; 1756). The Doha Ministerial Declaration upon the Conference in November 2001 clearly stressed the importance of "substantial improvements in market access; reductions of, with a view to phasing out, all forms of export subsidies; and substantial reductions in tradedistorting domestic support". At the same time, the document affirmed that "special and differential treatment for developing countries shall be an integral part of all elements of the negotiations". (WTO, 
2001)Brazil thus embarked upon the negotiations with optimistic initial expectations regarding the prospects of a positive outcome within agriculture (SOUZA, 2009, p. 58). Initially, Brazil worked closely with the free trade oriented agro-exporters in the Cairns Group. Yet, internal correspondences within Itamaraty indicate that by early 2003, the foreign establishment had begun to lose faith in the ability of this group as an effective tool to open protected markets (TELEGRAM. 552). The perception shared amongst many developing countries, that the previous agreements of GATT and WTO had resulted in asymmetrical outcomes in favor of developed economies, meant that Brazil was able to assume a leading position within what came to materialize as a North-South division (DOCTOR, 2015, p. 291). In the run-up to the Cancun Ministerial Conference in 2003, the G-20 coalition of developing countries was formed, within which Brazil obtained a pivotal role bycontesting the existing power structures at the level of international trade policy-making (CERVO, 2008, p. 107).The formation of the G-20 coalition not only served a functional end for Brazil as a negotiation tactic, but was also a move which reconciled a range of essential foreign policy objectives. As Vigevani and Cepaluni (2007) emphasize, the pursuit of "autonomy through diversification", referring to the proliferation and intensification of ties with other Southern countries, was a paramount concern and fundamental objective within the first Lula administration. This notion implies the perception of Southern coalitions and alliances as an important tool in order to reduce systemic asymmetries and enhance international bargaining capacity (VIGEVANI; CEPALUNI 2007, p. 282). Among the main foreign policy objectives at the outset of the first Lula government in 2003, Vaz (2003) similarly points to the search for alliances with other developing countries, and to the promotion of foreign trade as a means to support national development and to reduce unfavorable systemic vulnerabilities (VAZ, 2003, p. 146-148). The pursuit of increased market access for developing countries through the G-20 coalition thus served a crucial dual purpose by uniting these general objectives, and thereby satisfied both the interests affiliated with Brazilian agribusiness as well as the constituencies prioritizing an orientation towards Southern countries.

During the Doha Round, the strategic cooperation between Brazilian agribusiness and the state became a vital vehicle for the alternative trade agenda of the G-20 coalition (CARVALHO 2010, p. 419).Technical capacity was not exclusively located at the Itamaraty, but also in MAPA, ICONE and other significant stakeholders (PIMENTA JUNIOR, 2012, p. 81). Internal communication between MAPA and Itamaraty also reveals a strong mutual concern for promoting market 
access for Brazilian agriculture, and a high degree of internal coordination towards this end (NOTIFICATION; 118; 173; 006). Throughout the negotiations, private actors also came to assume a central functional importance within parts of Brazilian foreign policy. This is not necessarily equivalent to a decline in the relevance of Itamaraty, but rather means that its importance also has become related to systematically managing the many-folded demands and recourses at play within the foreign policy making process (CASON; POWER, 2010, p. 118-119). The technical backing, which made it possible for the Brazilian negotiators to present serious and wellresearched proposals, can thereby be seen as an input from civil society which was absorbed by the Foreign Ministry as part of a common strategy, perceived by Itamaraty as a national interest (DOCTOR, 2015, p. 290). Because of the economic significance of agriculture to the Brazilian economy, this sector's global market access may thereby be seen as a mutual concern between the foreign service and agribusiness (HOPEWELL, 2013, p.607). The possibility to define such trade-related objectives as compatible with the broader foreign policy goals was thereby an essential factor, which permitted the intimate relationship between private business and a governmental entity with a deeply rooted inclination towards autonomy within its institutional culture (HURREL; NARLIKAR, 2006, p. 430). This is reflected in the cooperation between Itamaraty, ICONE and CNA, which was based upon the sharing of information as well as the selective internalization of private sector inputs by the Foreign Ministry: The adoption of suggestions and tactics always happened on Itamaraty's own terms (DOCTOR, 2015, p. 292). Furthermore, the centralization of the decision-making process around the Foreign Ministry was also vital in order to ensure the formulation of policies which could sustain Brazil's leading role in the G-20 coalition. A more uncontested influence of Brazilian agribusiness interests would very likely have obstructed the possibility of reaching a common ground with countries more cautious towards liberalizations, such as India (RAMANZINI JUNIOR; MARIANO, 2013, p. 1222).

The G-20 groupwhich materialized at Cancun 2003 was characterized by a fairly broad range of different expectations and objectives, regarding an agreement about agriculture (DOCTOR, 2015, p. 291). In spite of the highly heterogeneous interests of the group, it served in order to push for an offensive position, which was harbored below the rhetoric of a 'Southern agenda' (VEIGA, 2005). Kirsten Hopewell refers to this as a process through which 'strategic mobilization' of divisions between North and South provided for promotion of the more particularistic interests of Brazil, and above all, 
its agribusiness sector (HOPEWELL, 2013, p. 618). Brazil's position within the G-20 coalition rested strongly upon functional and intellectual leadership. Its core functions within the group may be characterized as information sharing, knowledge inputs and the development and formulation of specific proposals. (PIMENTA JUNIOR, 2012, p. 79) In spite of lacking legal authority to define the Brazilian position, the Informal Technical Group became the de-facto principle decision-making body. Through their representation within this, agricultural interests-organizations were highly influential in defining the Brazilian objectives and strategies during the negotiations. (RAMANZINI JUNIOR; MARIANO, 2013, p. 1210) In this way, the domestic dimension became essential in order to explain the Brazilian role in the Doha Round. Compromises reached through balancing of different internal interests provided legitimacy at the level of the G-20 coalition (VEIGA, 2005). From 2005, the increased influence of Brazilian smallholder segments provided backing for the diplomatic efforts to breach divisions with coalition partners with a stronger concern for these groups (RAMANZINI JUNIOR; MARIANO 2013, p. 1219). Yet, as the strongest voices within Brazil were those associated with large-scale export-agriculture, their reluctance to accept the differential treatment and safeguards of other developing countries came to collide with the aspirations of G-20 coalition partners (Ibid, p. 1212-1213). The Brazilian agenda thereby approximated the traditional liberal paradigm prevalent within the WTO (HOPEWELL, 2013, p. 617-618) and superseded both developed and developing countries in demands for market opening. The divergence of interests between Brazil and its coalition partners was rooted in anextremely high degree of competitiveness of its agribusiness, otherwise rare amongst developing countries (Ibid, p. 617). Further complicating the matter, India and China did also themselves practice some form of agricultural protectionism (ALMEIDA, 2012, p. 95). In 2008, the Director General of the WTO, Pascal Lamy, presented a package of reform proposals which to some extend acceded to the demands of the G-20 coalition, through a tiered approach to tariff reduction and export subsidies. With the "Lamy Package", the divisions between the two principle nations within the G-20, Brazil and India, became clear as Brazil opted to join the proposal, while India rejected it. (PIMENTA JUNIOR, 2012, p. 68) The Brazilian adherence to the package was also strongly rooted in the divisions within the G-20, which by that time had become apparent (CARVALHO 2010, p. 437). By opting for a freemarked oriented regime for global agricultural trade, Brazil seems to have accommodated its highly competitive agribusiness sector, but on the other hand, ceded some credibility as a representative of 
developing countries (CARVALHO, 2010, p. 438). This indicates tensions within the Brazilian foreign policy, between on the one hand, trying to project itself as a leading figure within the third world "collective", and on the other hand, seeking status as a global power "individually" (HURREL; NARLIKAR, 2006, p. 430).

As emphasized by the institutionalist IPE perspectives, changes in global market structures have been interconnected with domestic institutional reconfiguration and the surge of new enterprise coalitions. Yet, the mobilization of rural interests has not been limited toaltering domestic institutions and policies, but has also been minded upon transforming market conditions at the international level. Moravcsik's (1998) liberal assumption of the state as a unitary actor, concerned with the aggregated preferences of its constituencies, partly describes the Brazilian state's efforts to manage agribusiness interests during commercial negotiations. So does his description of the dualism which determines the equilibrium guiding the state's participation in trade regulation, constituted by the encouragements of competitive producers opposed to the restraints of vulnerable segments. Yet, though smallholder constituencies were included within the process, their influence was not crucial and it did not alter the liberalizationoriented joint consensus and common external posture, between the state and agribusiness. The neopluralist perspective is particularly sensitive to the special relationship between government and business, as well as the diverse channels and mechanisms through which their cooperation materializes. Within the negotiations examined, such direct access, recourse pooling, knowledge sharing and institutionalized coordination between public and private agents enforced the leading Brazilian position. In spite of its roots within domestic politics, Lindblom'snotion of "mutual adjustment" thereby appears very adapt to conceptualize the collaborative international engagement between the state and private sectors.

\section{Conclusion}

The impact of fundamental changes in agricultural markets combined with the structural transformation of the Brazilian economy from the 1990s has led to a profound shift in the country's socioeconomic rural structure. Financialization, the incursion of foreign capital and the proliferation of industrial production and distribution systems are processes rooted in the transformation of international food markets. The transition from adevelopmentalist towards a liberal paradigm implied subsidy cuts, commercial opening and a thorough reorganization of the state's participation in rural development. The 
combined impact of these two movements reinforced the growth of a competitive export-oriented agribusiness sector, but at the same time, meant that many smallholders were put out of business and that rural exodus surged. In a situation of increased economic openness, agribusiness gained a central position within the state's strategy for international insertion, even after the partial reversion of the liberal paradigm with the election of a centre-left government in 2002. The export-oriented consensus between state and agribusiness resulted in a close cooperation to improve agricultural market conditions, through multilateral trade negotiations. At this sphere, the ties to agribusiness became an asset which ensured domestic backing as well as the technical expertise and organizational recourses which the agricultural sector could offer negotiators. Yet, this relationship in part also became a liability, because it was based upon a more radically liberal position which obstructed agreement with other developing countries. The undeniable economic significance that agribusiness has assumed in recent decades appears to have granted the sector a position of domestic leverage, which spills directly over into the Brazilian foreign engagement. This public-private alignment thus, seems to reflect the perception, that what is good for agribusiness, is good for Brazil.

\section{References}

AKSOY, A. M. The Evolution of Agricultural Trade Flows. In: AKSOY, A.M.; BEGHIN, J. C. (Org.) Global Agricultural Trade and Developing Countries.Washington D.C: The World Bank, 2005.

ALBANO, G. P; SÁ, A. J. Globalizacão da Agricultura: Multinacionais no Campo Brasileiro. Revista de Geografia, (UFPE) v. 28, n. 1, p. 54-80, 2011.

ALMEIDA, P.R. Relações Internacionais e Política Externa do Brasil: A diplomacia brasileira no contexto da globalização. Editoria Ltda: Rio de Janeiro, 2012.

ARBIX, G. Structural change and the emergence of the Brazilian MNEs.International Journal of Emerging Markets, v. 5, n. 3/4, p. 266-288, 2010.

BAN, C. Brazil's liberal neodevelopmentalism: New paradigm or edited orthodoxy? Review of International Political Economy, v. 20 n.2, p. 298331, 2012.

BELIK, W. Agroindústria e Política Agroindustrial no Brasil. In: RAMOS, P. (Org.) Dimensões do Agronegócio Brasileiro: Políticas Instituições e Perspetivas. Nead Estudos, MDA: Brasília, p.141-171, 2007.

BERALDO, A. D. As Negociações Agrícolas e a Evolução do Comércio Agrícola Mundial. Revista de Política Agrícola. MAPA, Ano IX, n. 4, .p. 3-9, 2000. 
BRAUN, M. B. S; LIMA, J. F; CARDOSO, R.D. Inserção Mundial e Competitividade da Agricultura Brasileira. Informe Gepec, v. 11, n. 1, p.3350, jan/jun, 2007.

BRAZIL LEI № 11.105, DE 24 DE MARÇO DE 2005. Presidência da República. Casa Civil, Subchefia para Assuntos Estratégicos.

BUTTEL, F. H. Some Reflectionon Late Twenteeth Century Agrarian Economy. Cadernos de Ciência \& Tecnologia. v. 18, n. 2, p. 11-36, maio/ago, 2001.

CARVALHO, M. I. V. Estruturas Domésticas e Grupos de Interesse: a Formação da Posição Brasileira para Seattle. Contexto Internacional, v. 25, n. 2. p. 363401, 2003.

CARVALHO, M. I. V. Condicionantes Internacionais e Domésticos: O Brasil e o G-20 nas Negociações Agrícolas da Rodada Doha, Revista de Ciências Sociais, vol. 53, núm. 2, p.405-438, 2010.

CARVALHO, S. B. Primeiro mandato do governo Lula (2003-2006): uma revisão deliteratura, II Seminário Dos Cursos das Ciencias Sociais Applicadas da Fecilcam, p. 1-10, 2011.

CASON, J. W.; POWER, T.J. Presidentialization, Pluralization, and the Rollback of Itamaraty: Explaining Change in Brazilian Foreign Policy Making in the Cardoso-Lula Era. International Political Science Review, v. 30, n. 2, p.117$140,2009$.

CAVALCANTI J. F. B; KRONE, E. E. Brazilian Farmers, Quality and Markets. In: BONANNO, A. \& BUSCH, L. (Orgs.) Handbook of the International Political Economy of Agriculture and Food. Cheltenham: Edward Elgar Pub. 2015.

CERVO, A. L. Inserção Internacional: Formação dos Conceitos Brasileiros. São Paulo: Saraiva, 2008.

CERVO, A. L. \& BUENO, C. História da política exterior do Brasil. Brasília: Editora UnB, 2011.

COELHO, C. N. A Política Agrícola e o Endividamento do Setor Rural, Revista de Política Agrícola, MAPA, Ano VIII. n.04 p. 11-32, 1999.

COELHO, C. N. \& WERNECK, P. O Acordo Agrícola da OMC e a Cláusula da Paz. Revista de Política Agrícola, MAPA, Ano XIII - No 1, ISSN 1413-4969, p.5-16, 2004.

COLEMAN, W. D. Globality and Transnational Policy-Making in Agriculture, Institute on Globalization and the Human Condition, Working Paper Series, p.1-17, June 2003.

CONAB a, - Companhia Nacional de Abastecimento. Prêmio para Escoamento de Produto - PEP. [online] Available: http://www.conab.gov.br Access: 11/12, 2015.

CONAB b, - Companhia Nacional de Abastecimento. Contrato de Opção de Venda [online] Available: http://www.conab.gov.br Access: 11/12, 2015.

CORTE, T. D. O Processo de Internacionalização do Agronegócio Brasileiro: Os Fatores Determinantes Para Sua Consolidação, seus 
Desafio e seus Gargalhos. Anais Eletrônicos do II Cong. Int. de His. Reg. ISSN 2318-6208, 2013.

DEADORF, A. V.; STERN, R. M. Alternatives to the Doha Round. Journal of Policy Modeling, 31, p.526-539, 2009.

DE MELO, F. H. O Plano Real e a Agricultura Brasileira: Perspectivos. Revista de Economia Política, v. 14, n. 4. p. 146-155, 1999.

DIEGO-FERNANDES, M. Trade Negotiations Make Strage Bedfellows.World Trade Review, v. 7, Issue 02, p 423 - 453,april, 2008.

DINIZ, E. As elites empresariais e a Nova República: corporativismo, democracia e reformas liberais no Brasil dos anos 90. Ensaios FEE, Porto Alegre (17)2:55-79, p.55-79, 1996.

DOCTOR, M. Brazil's Role in Institutions of Global Economic Governance: The WTO and G20. Global Society, v. 29, n. 3, p. 286-300, 2015.

ENGELMAN, S. I; GIL, A.D. A questão agrária no Brasil: a política agrária dogoverno Lula e a relação com o MST. Revista Eletrônica do CEMOP - n. 02,p.1-9,2012.

FAIRBAIRN, M. Finance and the Food System. In: BONANNO, A. \& BUSCH, L. (Orgs.) Handbook of the International Political Economy of Agriculture and Food. Cheltenham: Edward Elgar Pub, 2015

FAO - Food and Agricultural Organization of the United Nations.FAOSTAT.World production sorted by quantity. Available from: http://faostat.fao.org/site/339/default.aspx, [Access: 30/4, 2016].

FRIEDEN.J. A.; ROGOWSKI, R. The impact of the international economy on national policies: an analytical overview. In: KEOHANE, R.; MILNER, H. (Org.), Internationalization and Domestic Politics. Cambridge: Cambridge University Press, 1996.

HOPEWELL, K. New Protagonists in Global Economic Governance: Brazilian Agribusiness at the WT0. New Political Economy, v. 18, n. 4, p.603-623, 2013.

HOPEWELL, K. The transformation of state-business relations in an emerging economy: The case of Brazilian agribusiness.Critical perspectives on international business, v. 10 n. 4, p. 291-309, 2014.

HUMMELS, D. Transportation Costs and International Trade in the Second Era of Globalization.Journal of Economic Perspectives, vol. 21, nr. 3, p.131154, 2007.

HURREL, A.; NARLIKAR, A. A New Politics of Confrontation? Brazil and India in Multilateral Trade Negotiations.Global Society, v. 20, No. 4, p.415-433, 2006.

IBGE - Instituto Brasileiro de Geografia e Economia. 2016 Séries; Historicas é Estadistidas, Lavoura temporária - área plantada. PA01[online] Available from:

http://seriesestatisticas.ibge.gov.br/lista_tema.aspx?op=0\&no=1.[Accessed: 29/4, 2016]. 
IBGE - Instituto Brasileiro de Geografia e Estatística. 2006. Agricultura Familiar, Primeiros Resultados, Brasil, Grandes Regiões e Unidades da Federacão. CensoAgropecuário,2006.

JANK, M.S.; FUCHLOCH, I.; KUTAS, G. Agricultural liberalization in multilateral and regionaltrade negotiations. In: JANK, M. S. (Org.) Agricultural Trade Liberalization, Implications for Latin America. Washington: IDB Publications, 2004.

LESSA, C.A.; COUTO, L. F.; FARIAS, R. S. Política externa planejada: os planos plurianuais e a ação internacional do Brasil, de Cardoso a Lula (1995-2008). Rev. Bras. Polít.Int. 52 (1).p. 89-109, 2009.

LINDBLOM, C. E. WOODHOUSE, E. J. The Policy Making Process, 3rd Edition. New Jersey: Prentice Hall, 1993.

LINDBLOM, C. E. Politics and Markets.The World's Political Economic Systems.New York: Basic Books Inc, 1977.

LOPES M. R.; SOUZA, G. S; ROCHA, D. P.; LOPES, I. V.; HONCZAR, G. Quem São e Como Decidem os Agricultores Líderes da Agropecuária Brasileira. Revista de Política Agrícola. MAPA, Ano XI, n.2, p. 21-30, 2002.

MAPA - Ministry of Agriculture, Livestock and Food Supply. Brazilian Agriculture at a Glance. ISBN 978-85-7991-034-0. Brasilia, 2010.

MENDONÇA, M. L. O Papel da Agricultura nas Relações Internacionais e a Construção de Conceito de Agronegócio. Contexto Internacional, v. 37, n. 2.p. 375-402, 2015.

MILNER, H; KEOHANE, R. Internationalization and Domestic Politics: An introduction. In: KEOHANE, R. \& MILLNER, H. (Org.) Internationalization and Domestic Politics. Cambridge: Cambridge University Press, 1996.

MORAVCSIK, A. Taking preferences seriously: a liberal theory of international politics.International Organization, vol.51, no.4. p.513-553, 1997.

MORAVCSIK, A.The choice for Europe: social purpose and state power from Messina to Maastricht. London: Routledge, 1998.

MULLER, B.; MULLER, C. The Economics of the Brazilian Model of Agricultural Development. IRIBA Working Paper: 01, ISBN 978-1-91050200-6, 2014.

MURPHY, S; BURCH, D; CLAPP, J. Cereal Secrets; The World's Largest Grain Traders and Global Agriculture. Oxfam Research Reports.ISBN 978-178077-150-2. Oxford: Oxfam. August, 2012.

NASCIMENTO, J. R. Analysis of International Investments in the Agricultural Sector of Brazil.Food and Agriculture Organization of the United Nations.Trade and Markets Division (EST).Policy Assistance Support Services (TCSP). Brasília, 2011.

NOTIFICATION 118.Notification from Ministry of Agriculture, Livestock and Provisioning (MAPA) to the Foreign Ministry, December 19, 2001.

NOTIFICATION 173.Notification from Ministry of Agriculture, Livestock and Provisioning (MAPA) to the Foreign Ministry, June 7, 2002. 
NOTIFICATION 006.Notification from the Foreign Ministry to theMinistry of Agriculture, Livestock and Provisioning (MAPA), July 1, 2002.

PAULA, N. \& BASTOS L.T. Brazilian agribusiness's insertion in global markets.Estud.soc. agric. vol.4, p.302-331, 2008.

PEINE, E. The Private State of Agribusiness: Brazilian Soy on the Frontier of a New Food Regime. Cornell. PhD Thesis (Doctorate in Phil.). Cornell University, 2009.

PIMENTA JUNIOR, J. L. Coalizões Internacionais e o G-20: Aspectos da Liderança Brasileira na Rodada Doha de Desenvolvimento da OMC. Dissertação de mestrado. (Mes. em Relações Internacionais). São Paulo, Ins. de Rel. Int. USP, 2012.

RAMANZINI JUNIOR, H; MARIANO, M. P. Brazil and the G-20: Domestic Pressures and the Construction of the Negotiating Position in the Doha Round of the WTO, Journal of World Tradev.47, n. 6 p.1203-1224, 2013.

REZENDE, G. R. Conjuntura Macroeconômica e Política Agrícola no Período 1992/97: dos Velhos aos Novos Instrumentos. Revista de Política Agrícola, Ano VIII, n. 03, 1999.

RODRIGUES, R. 0 Papel do Setor Privado e os Novos Desafios do Abastecimento Nacional. Revista de Política Agrícola, MAPA. Ano X, n.1, p.712, 2001.

RODRIGUES, W. \& DE LUCENA, A. F. Abertura comercial na década de 1990 Reflexões sobre o Brasil. In: BENECKE, D. W; NASCIMENTO, R; FEDNT, R. (Org.) Brasil na Arquitetura Comercial Global. p.409-416. Rio de Janeiro: Fundação Konrad Adenauer, 2003.

SABA, S. Comercio Internacional e Política Externa Brasileira. Porto Alegre: Livraria do Advogado, 2002.

SCHLESINGER, S. Soja: el grano que siguecreciendo.Grupo de Trabajo sobre Desarrollo y Medio Ambiente enlas Américas, Trabajo de Discusión, No. 21. p. 1-23, 2008.

SOUZA, A. A Agenda Internacional do Brasil. Rio de Janeiro: Elsevier, 2009.

TAGLiALEGNA, G. H. F; BRACALE, G; MANDAI, K; SOUSA, E. L. L. Papel da Agricultura no Plano Real: Estabilização da Moeda e Modernização do Setor. Revista de Política Agrícola, MAPA, Ano IX, n. 03, p.40-46, 2000.

TELEGRAM. 1756. Telegram from Brazilian delegation at the WTO in Genève to the Foreign Ministry in Brasília, 12/10/2001

TELEGRAM.1311. Telegram from Brazilian delegation at the WTO in Genève to the Foreign Ministry in Brasília, 27/07/2001

TELEGRAM. 552. Telegram from Brazilian delegation at the WTO in Genève to the Foreign Ministry in Brasília, 13/03/2003

THORSTENSEN, V. OMC Organização Mundial do Comércio: as regras do comércio internacional e a rodada do milênio. 2 ed. São Paulo: Aduaneiras, 2005. 
VAZ, A. C. El gobierno Lula ¿Una nueva política exterior? Nueva Sociedad 187, p. 39-52, 2003.

VEIGA, P. M. Brazil and the G-20 Group of Developing Countries. WTO Online publications.Managing the Challenges of WTO Participation. 2005 [online] Available from: http://www.wto.org [Accessed: 22/11, 2015].

VIEIRA, R. C. M. T; FILHO, A. R. T; OLIVEIRA, R. J; LOPES, M. R. Cadeias Produtivas no Brasil - Análise e Competitividade. Revista de Política Agrícola, MAPA, Ano X - n. 04, p.7-15, 2001.

VIEIRA, V. R. Is Politics Behind Trade? The Impact of International Trends and Diplomatic Action on Brazil's Exports during Globalisation.Bulletin of Latin American Research, v. 33, n. 2, p. 140-157, 2014. VIGEVANI, T.; CEPALUNI, G. Lula da Silva's foreign policy: the autonomy through diversification strategy. Contexto Internacional, v. 29, n. 2, p. 273$335,2007$.

WARnken, P. O Futuro da Soja no Brasil. Revista de Política Agrícola, MAPA, Ano IX, n. 2, p.54-65, 2000.

WATANABE, K; ZYLBERSZTAJN D. Contract farming in the Brazilian agribusiness system: private institutions and State intervention. Unif. L. Rev. v. 19, p. 459-478, 2014.

WELCH, C. Globalization and the Transformation of Work in Rural Brazil: Agribusiness, Rural Labor Unions, and Peasant Mobilization. International Labor and Working-Class History, n. 70, p. 35-60, fall. 2006.

WORLD BANK. Indicators. Employment in agriculture. worldbank.org. Available from:

http://data.worldbank.org/indicator/SL.AGR.EMPL.ZS/countries?page=1. [Access: 29/4 2016]

WTO, Ministerial 2001, Ministerial Declaration.Adopted on Nov. 142001. [online] Available from: www.wto.com Accessed: Dec 4, 2015.

Recebido em 19 de dezembro de 2015

Aprovado em 18 de fevereiro de 2016 


\section{Realinhamentos entre público e privado: o papel das transformações estruturais no fomento do engajamento internacional do agronegócio e o Estado brasileiro}

\section{Resumo}

0 artigo analisa como mudanças em mercados agrícolas globais e a transformação estrutural da economia brasileira a partir dos anos 1990 têm redefinido as relações Estado-agronegócio, e como isto tem influenciado na estratégia internacional do país. 0 objetivo central é avaliar o impacto causal de fatores estruturais no nível global e nacional nas disposições e preferências do grupo de atores examinados. A cooperação público-privada é analisada por meio de literatura institucionalista de economia política internacional e teoria liberal das relações internacionais, em combinação com a perspectiva neopluralista. 0 artigo conclui que mudanças em mercados de alimentos globais e as liberalizações econômicas a partir dos anos 1990 têm fomentado um consenso de exportação entre o setor agrícola e o estado, com fortes repercussões no engajamento internacional do país.

Palavras-chave: Agricultura, Grupos de Interesse, Agronegócio, Comércio Internacional, OMC. 